\title{
Thermo-mechanical controls on geothermal energy resources: case studies in the Pannonian Basin and other natural laboratories
}

\author{
Sierd Cloetingh $^{1} \cdot$ Jan-Diederik Van Wees ${ }^{1,2} \cdot$ \\ Viktor Wesztergom ${ }^{3}$
}

Received: 22 March 2017/Accepted: 31 March 2017/Published online: 7 April 2017

(C) Akadémiai Kiadó 2017

Geothermal energy is an important renewable energy resource, whose share is growing rapidly in the energy mix. Geosciences provide fundamental knowledge on Earth system processes and properties, required for the development of new methods to identify prospective geothermal resources suitable for exploitation. Through robust prediction and detection of critical reservoir parameters, including rock fabric, temperature, in situ stress, flow properties and fluid geochemistry, it is possible to reduce pre-drilling risks for geothermal exploration.

This special issue of AGG on Geothermal Energy deals with improved in-depth understanding of the subsurface processes and properties of relevance for geothermal exploration and production. It covers a variety of multidisciplinary approaches acting on different spatial and temporal scales, underpinned by field evidence and subsurface data in a selection of prospective areas for enhanced geothermal systems in Europe (Fig. 1). In particular, advances in understanding thermo-mechanical controls (cf. Cloetingh et al. 2013; Tesauro et al. 2009) on reservoir quality and stimulation potential (e.g. Wassing et al. 2014) are key for the development of deep geothermal resources, including enhanced geothermal systems (Cloetingh et al. 2010). The majority of the papers focus on case studies of the Pannonian Basin, whereas others have direct relevance to natural laboratories in the Netherlands and Spain. Together they highlight the high impact of geothermal research on geothermal resource development across Europe.

Lenkey et al. (2017, this volume) compare different lithosphere model approaches for thermal prediction and conclude that transient effects of active lithosphere deformation and groundwater flow need to be taken into account in regional- to local-scale models to

Sierd Cloetingh

S.A.P.L.Cloetingh@uu.nl

1 Faculty of Geosciences, Utrecht University, Princetonlaan 6, Utrecht, The Netherlands

2 TNO, Geological Survey of the Netherlands, Princetonlaan 6, Utrecht, The Netherlands

3 MTA CSFK Geodetic and Geophysical Institute, Csatkai u. 6-8, Sopron 9400, Hungary 


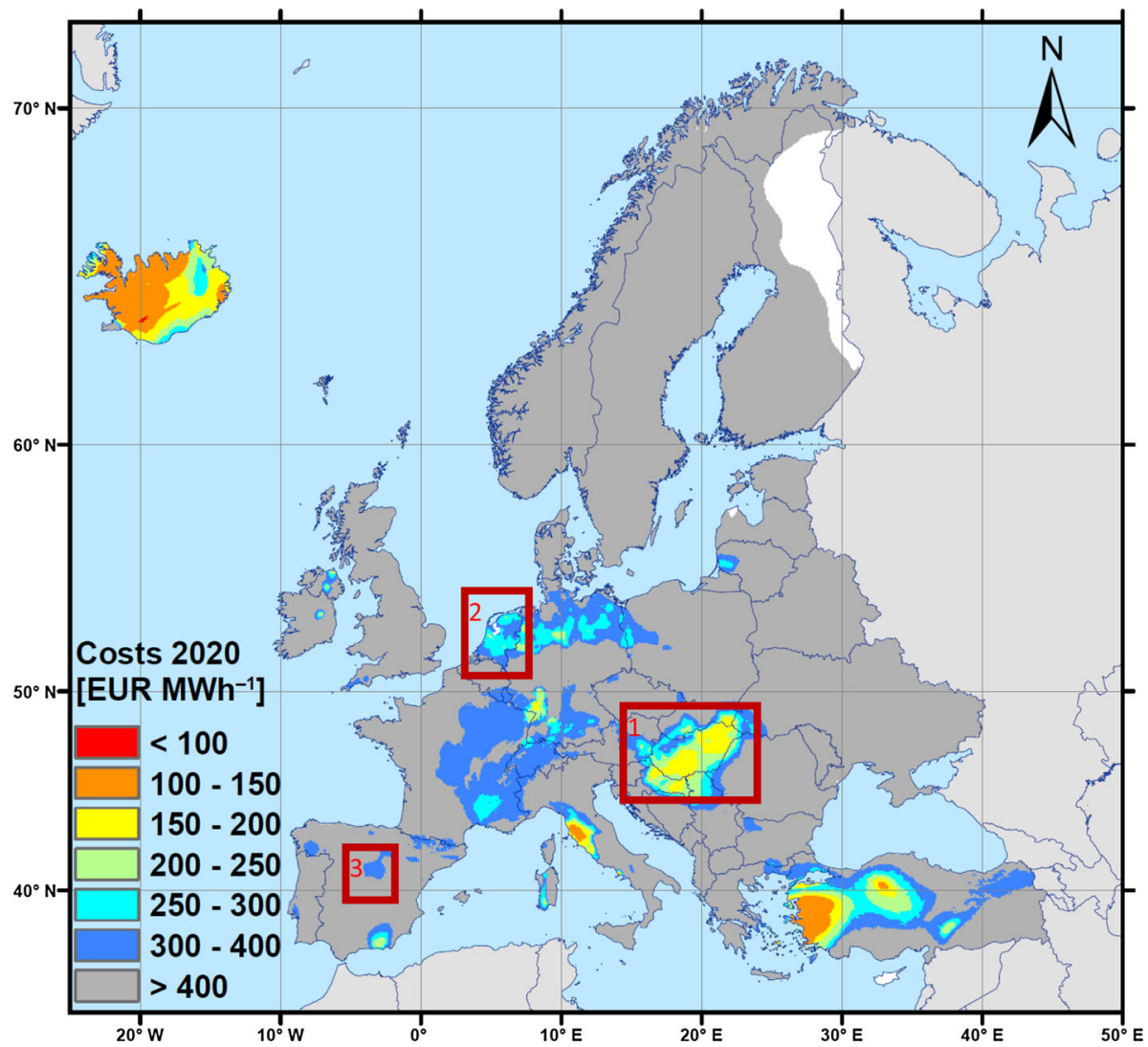

Fig. 1 Location of case studies presented in this paper. (1) Pannonian Basin, (2) The Netherlands, (3) Central System of Iberia. Map after Limberger et al. (2014), shows estimated Levelized Costs of Energy for enhanced geothermal systems

accurately predict temperatures in potential geothermal reservoirs. Their conceptual models have been tested and validated in the Pannonian Basin and provide improved thermal constraints for the exploration of Enhanced Geothermal System exploration (EGS).

In the central Pannonian Basin region there is a relatively small mismatch $(<5 \mathrm{~km})$ between the thermally estimated depth of the solidus from surface heat flow and the geophysically determined LAB from seismic velocities. Kovács et al. (2017, this volume) introduce a simple petrologic model that could explain strong geophysical anomalies (e.g. seismic velocity). It is found that the dehydration solidus of pargasitic amphibole-bearing upper mantle with very low bulk water (hundreds ppm) may lead to partial melting at $1050-1100{ }^{\circ} \mathrm{C}$ at a $30-90 \mathrm{~km}$ depth range. This model therefore provides an independent method to improve the robustness of deep sedimentary basin and basement temperatures, relevant for deep geothermal exploration.

The identification of geothermal resources is critically dependent on the development and application of novel and cost-effective exploration methods. One of the most promising methods for deep prospecting is the magnetotelluric (MT) method. Ádám et al. (2016, this volume), demonstrate the resolution power of MT, present results on deep electrical conductivity anomalies in the Pannonian Basin, and put its relevance in 
perspective of in-depth understanding of the deep basin and lithosphere structure, and geodynamic aspects. Békési et al. (2017, this volume) present a comprehensive analysis of the Double-difference relocation of the 29 January 2011 ML 4.5 Oroszlány earthquake in the Pannonian Basin and its aftershocks. They highlight its relevance to improved understanding of the seismogenic part of the lithosphere, its underlying rheology and geothermal prospectivity in view of fracture permeability and stimulation potential.

Clastic sedimentary aquifers can be excellent geothermal reservoirs (e.g. Van Wees et al. 2017). The flow performance of clastic rocks tends to be strongly dependent on mechanical compaction, which in turn is a function of maximum burial depth. Worum and Van Wees (2017, this volume), present a robust multi-disciplinary geological (structural analysis) and petrophysical (sonic-velocity) method to assess burial anomalies, and its implications for prediction of reservoir quality. The method is demonstrated in the Netherlands.

Limberger et al. (this volume, 2017), present a freely available 1D thermal and rheological model for basement-sedimentary areas. This tool helps to understand variability of deep temperatures, as an effect of uncertainties in thermal and rheological properties and tectonic constraints for the lithosphere, important for assessing geothermal prospectivity. The tool is demonstrated on the Central System in Spain and the adjacent Tajo and Duero basins.

Finally, it should be noted that the research presented in this special issue showcases the added value of synergy in international research collaboration, as most of the presented work has been performed in the framework of various international (mostly EU) funded collaborations, including the Joint Programme of Geothermal Energy in the European Energy Research Alliance (EERA-JPGE) and the International Lithosphere Project (ILP).

\section{References}

Ádám A, Szarka L, Novák A, Wesztergom V (2016) Key results on deep electrical conductivity anomalies in the Pannonian Basin (PB), and their geodynamic aspects. Acta Geod Geophys. doi:10.1007/s40328016-0192-2

Békési E, Süle B, Lenkey L, Lenkey-BőgérA Bondár I (2017) Double-difference relocation of the 29 January 2011 ML 4.5 Oroszlány earthquake and its aftershocks and its relevance to the rheology of the lithosphere and geothermal prospectivity. Acta Geod Geophys. doi:10.1007/s40328-017-0195-7

Cloetingh S, Van Wees JD, Ziegler P, Lenkey L, Beekman F, Tesauro M, Förster A, Norden B, Kaban M, Hardebol N, Bonté D, Genter A, Guillou-Frottier L, Voorde MT, Sokoutis D, Willingshofer E, Cornu T, Worum G (2010) Lithosphere tectonics and thermo-mechanical properties: an integrated modelling approach for Enhanced Geothermal Systems exploration in Europe. Earth-Sci Rev 102:159-206

Cloetingh S, Willet S, Torsvik T, Werner S (eds) Topo-Europe III, 2013. Tectonophysics 602:1-381

Kovács I, Lenkey L, Green DH, Fancsik T, Falus G, Kiss J, Orosz L, Angyal J, Vikor Z (2017) The role of pargasitic amphibole in the formation of major geophysical discontinuities in the shallow upper mantle. Acta Geod Geophys. doi:10.1007/s40328-016-0191-3

Lenkey L, Raáb D, Goetzl G, Lapanje A, Nádor A, Rajver D, Rotár-Szalkai Á, Svasta J, Zekiri F (2017) Lithospheric scale 3D thermal model of the Alpine-Pannonian transition zone. Acta Geod Geophys. doi:10.1007/s40328-017-0194-8

Limberger J, Calcagno P, Manzella A, Trumpy E, Boxem T, van Pluymaekers M, Wees JD (2014) Assessing the prospective resource base for enhanced geothermal systems in Europe. Geothermal Energy Sci 2:55-71

Limberger J, Bonte D, de Vicente G, Beekman F, Cloetingh S, van Wees JD (2017) A public domain model for 1D temperature and rheology construction in basement-sedimentary geothermal exploration: an application to the Spanish Central System and adjacent basins. Acta Geod Geophys. doi:10.1007/ s40328-017-0197-5 
Tesauro M, Kaban MK, Cloetingh SAPL (2009) A new thermal and rheological model of the European lithosphere. Tectonophysics 476:478-495

Van Wees JD, Veldkamp H, Pluymaekers J, Gessel S, Bonte D (2017) Unlocking geothermal energy in mature oil and gas basins: the Netherlands success story. In: Bertani R (ed) New perspectives for geothermal energy in Europe. ICL press, London

Wassing B, Van Wees JD, Fokker P (2014) Coupled continuum modeling of fracture reactivation and induced seismicity during enhanced geothermal operations. Geothermics 52:153-164

Worum G, van Wees J-D (2017) High-resolution quantitative reconstruction of Late Cretaceous-Tertiary erosion in the West Netherlands Basin using multi-formation compaction trends and seismic data: implications for geothermal exploration. Acta Geod Geophys. doi:10.1007/s40328-017-0196-6 